\title{
MODEL PEMBELAJARAN PENJAS MELALUI PERMAINAN UNTUK PEMBENTUKAN KARAKTER KERJA SAMA, TANGGUNG JAWAB DAN KEJUJURAN SISWA SD
}

\section{GAME MODELS OF PHYSICAL ACTIVITY FOR CHARACTER BUILDING COOPERATION, RESPONSIBILITY AND HONESTY FOR ELEMENTARYS SCHOOL STUDENT}

\author{
Rubiyatno, Suharjana \\ PPs UNY, Universitas Negeri Yogyakarta \\ rubiyatno32@yahoo.com, suharjana_fikuny@yahoo.com
}

\begin{abstract}
Abstrak
Penelitian ini bertujuan untuk menghasilkan model pembelajaran penjas melalui aktivitas permainan bagi siswa sekolah dasar khususnya kelas atas yang terintegrasi dengan nilai-nilai karakter kerja sama, tanggung jawab dan kejujuran. Penelitian pengembangan ini dilakukan dengan mengadaptasi langkah-langkah penelitian pengembangan sebagai berikut: (1) pengumpulan informasi di lapangan dan melakukan analisis terhadap informasi yang telah dikumpulkan, (2) mengembangkan produk awal (draf model), (3) validasi ahli dan revisi, (4) uji coba lapangan skala kecil dan revisi, (5) uji coba lapangan skala besar dan revisi, dan (6) pembuatan produk final. Instrumen pengumpulan data yang digunakan yaitu: (1) pedoman wawancara, (2) skala nilai, (3) pedoman observasi permainan, (4) pedoman observasi keefektifan permainan, dan (5) pedoman observasi terhadap guru pelaku uji coba. Teknik analisis data yang digunakan yaitu analisis deskriptif kuantitatif dan analisis deskriptif kualitatif. Hasil penelitian ini berupa buku panduan aktivitas permainan untuk pembentukan karakter kerja sama, tanggung jawab dan kejujuran siswa sekolah dasar kelas atas, yang berisikan enam jenis permainan, yaitu: (1) permainan berburu kancil, (2) permainan perang bola, (3) permainan memasukkan bola ke simpai, (4) permainan golku keranjangku, (5) permainan lempar tangkap, dan (6) permainan sentuh bola yang telah divalidasi oleh ahli dan guru.
\end{abstract}

Kata kunci: model pembelajaran, karakter, dan siswa SD.

\section{Abstract}

This study aims at delivering game models for especially top grade elementary school students to build character, cooperation, responsibility and honesty that are ready to use. The teachers are expected to use this game model as one of integrated character value instructional forms that is appropriate and effective through enjoyable playing activities.This educational research and development $(R \& D)$ was conducted by adapting $R \& D$ steps consisting of: (1) collecting information and information analysis, (2) developing initial product, (3) expert validation and revision, (4) preliminary field test and revision, (5) main field test and revision, and (6) making the final product. The preliminary field test was conducted to 14 students year 5 of SD.N.Pantaran Kulon Progo and the main field test was conducted to 40 students Class 4 and 5 of SD.N.2 Kalipetir Pengasih Kulon Progo. Data collecting instrument used were: (1) interview guide, (2) rating scale, (3) observation guide for games observation, (4) observation guide for games effectiveness, and (5) observation guide for perpetrator teachers. The data were analyzed using quantitative descriptive analysis and qualitative descriptive analysis.The result of this study is in the form of a game guidance book of integrated character building for corporation, responsibility, and honesty in the form of physical activities for upper grade elementary school students, consisting of six games: (1) blast fishing game, (2) ball war game, (3) shoot the ball to the hula hoop game, (4) my goal and basket game, (5) volley throw and catch, and (6) touching ball to the body game. As a conclusion, the game models are very good and effective to transfer character value, corporation, responsibility, and honesty

Keywords: model of learning, character and elemantary students. 


\section{Pendahuluan}

Indonesia merupakan bangsa yang memiliki keanekaragaman budaya. Ketika bangsa Indonesia bersepakat untuk memproklamasikan kemerdekaan Indonesia pada tanggal 17 Agustus 1945, para pendiri bangsa (the founding father) menyadari bahwa ada beberapa tantangan besar yang harus dihadapi. Pertama, mendirikan negara yang bersatu dan berdaulat, kedua membangun bangsa, dan ketiga membangun karakter. Ketiga hal tersebut secara jelas tampak dalam konsep negara dan pembangunan karakter bangsa (nation and character building). Melihat kondisi bangsa Indonesia yang belum solid, belum kukuh, dan terbelah-belah, maka sebagai suatu bangsa yang merdeka dan berdaulat, perlu terus mengupayakan terciptanya warga negara yang berkarakter mulia dan bermartabat. Bangsa Indonesia yang memiliki kejelasan dan kebanggaan identitas diri merupakan impian dan cita-cita bagi semua warga negara Indonesia.

Pendidikan karakter dapat dilakukan bersamaan dengan kegiatan belajar mengajar yang diintegrasikan dalam setiap mata pelajaran termasuk penjas dan olahraga. Pendidikan jasmani tersebut tidak hanya merupakan sebuah gerak badan, tapi juga alat yang strategis untuk membina karakter. Menurut Doty (2006, p.1) People participate in sports for a variety of reasons health and fitness, stress management, socialization, relaxation, and others. One of the "other" reasons is character development. Di dalam penjas dan olahraga banyak terkandung nilai-nilai karakter seperti sportivitas, kejujuran, keberanian, kerja keras, pengendalian diri, tanggung jawab, kerja sama, keadilan, dan kebijaksanaan, menghargai lawan dan sebagainya yang dapat diintegrasikan dalam aktivitas gerak dan dalam berbagai bentuk permainan. Dari pernyataan di atas jelas bahwa pendidikan jasmani dan olahraga dapat menjadi ujung tombak dalam mengubah karakter bangsa Indonesia menjadi lebih kuat.

Anak-anak adalah generasi yang akan menentukan nasib bangsa di kemudian hari. Karakter anak-anak yang terbentuk sejak sekarang akan sangat menentukan karakter bangsa di masa yang akan datang. Karakter anak-anak akan terbentuk dengan baik, jika dalam proses tumbuh kembangnya mendapatkan cukup ruang untuk mengekspresikan diri secara leluasa khususnya dalam aktivitas bermain.
Oleh karena itu peneliti yakin, lewat permainan aktivitas jasmani upaya untuk membentuk karakter anak usia sekolah dasar khususnya kelas atas akan dapat dilakukan, sehingga peneliti tertarik untuk membuat modelmodel permainan aktivitas jasmani yang di dalamnya terkandung nilai-nilai karakter positif untuk anak sekolah dasar. Peneliti berasumsi bahwa dengan membuat model-model permainan tersebut anak tidak hanya sebatas mengetahui nilai-nilai karakter yang baik, namun mau melakukan tindakan tersebut dan nantinya diharapkan menjadi habituasi (kebiasaan) dalam diri anak, sehingga diharapkan penerus bangsa ini nantinya akan memiliki karakter yang kuat sesuai dengan nilai-nilai luhur yang terkandung di dalam Pancasila.

Menurut Samani (2011, p.42) karakter adalah perilaku yang tampak dalam kehidupan sehari-hari baik dalam bersikap maupun dalam bertindak. Menurut Kamus Besar Bahasa Indonesia (2008) karakter merupakan sifat-sifat kejiwaan, akhlak atau budi pekerti yang membedakan setiap individu dengan individu lainnya. Lebih lanjut menurut Munir (2010, p.3) karakter adalah sebuah pola, baik itu pikiran, sikap, maupun tindakan, yang melekat pada diri seseorang dan sulit dihilangkan.

Menurut Muin (2011, p.160) menyatakan bahwa karakter sama dengan kepribadian, Kepribadian dianggap sebagai ciri, atau karakteristik, gaya, atau sifat khas dari diri seseorang yang bersumber dari bentukan-bentukan yang diterima dari lingkungan misalnya keluarga pada masa kecil, juga bawaan sejak lahir. Karakter merupakan kumpulan tata nilai yang menuju pada satu sistem, yang melandasi pemikiran, sikap dan perilaku yang ditampilkan. Lebih lanjut Milson (2002, p.101) menyatakan virtue of character is a result of habituation. from this it is clear that none of the virtues of character arises in us by nature. Disimpulkan bahwa karakter merupakan cara berfikir dan berperilaku yang menjadi ciri khas setiap individu terkait dengan nilai benar salah, dan nilai baik buruk, sehingga karakter akan muncul menjadi kebiasaan yang termanifestasi dalam sikap dan perilaku.

\section{Metode}

\section{Model Pengembangan}

Penelitian ini merupakan penelitian pengembangan (research and development). Dalam hal ini pengembangan dilaksanakan untuk 
mendapatkan sebuah model permainan untuk pembentukan karakter kerja sama dan tanggung jawab bagi anak sekolah dasar kelas atas. Pengembangan ini dilakukan berdasarkan pada kajian terhadap muatan kurikulum yang ada dalam proses pembelajaran pendidikan jasmani di sekolah dasar terutama kelas atas, Kemudian dalam melakukan pengembangan, pada tahap pemilihan bentuk aktivitas yang dikembangkan juga melihat pada tahap-tahap perkembangan serta karakteristik anak, sehinngga model yang dihasilkan diharapkan cocok atau sesuai anak dan tahapan perkembanganya.

Prosedur Pengembangan

Prosedur pengembangan dalam penelitian ini direncanakan menggunakan langkahlangkah penelitian pengembangan menurut Borg dan Gall. Menurut Borg dan Gall (1983, p.775) dalam melakukan penelitian pengembangan terdapat 10 langkah yang harus ditempuh sebagai berikut:(1) pengumpulan hasil riset, (2) Perencanaan, (3) mengembangkan produk awal, (4) uji coba awal, (5) revisi untuk menyusun produk utama, (6) uji coba lapangan utama, (7) revisi untuk menyusun produk operasional, (8) uji coba produk operasional, (9) revisi produk final, dan (10) diseminasi dan implementasi produk hasil pengembangan. Kemudian langkah-langkah tersebut diadaptasi menjadi 6 tahapan sebagai berikut: (1) Studi pendahuluan dengan melakukan pengumpulan informasi dan analisis terhadap informasi yang telah dikumpulkan, (2) mengembangkan produk awal, (3) validasi ahli dan revisi, (4) uji coba lapangan dengan skala kecil dan revisi produk, (5) uji coba skala besar dan revisi produk (6) produk akhir.

Desain Uji Coba

Uji coba dilakukan dengan tujuan untuk menyempurnakan model permainan dengan memraktekkannya secara langsung di lapangan. Dalam penelitian ini, uji coba produk/draf model dilakukan sebanyak dua kali, yaitu uji coba skala kecil dan uji coba skala besar. Uji coba produk skala kecil dilakukan terhadap siswa kelas V SDN Pantaran Kulon Progo yang berjumlah 14 orang, sementara uji coba skala besar dilakukan terhadap siswa kelas IV dan V SDN 2 Kalipetir Pengasih Kulonprogo. Kemudian dalam tahap uji coba di lapangan peran peran dari para pakar serta guru Penjas adalah untuk mengobservasi kelayakan draf model yang telah disusun dengan kenyataan di lapang- an kemudian setelah uji coba skala luas maka akan menghasilkan sebuah model yang benarbenar valid.

\section{Subjek Coba}

Subjek coba pada penelitian ini yaitu siswa kelas 5 dari SDN Pantaran Kulon Progo dan siswa kelas 4 dan 5 dari SDN 2 Kalipetir Pengasih Kulon Progo. Uji coba skala kecil dilakukan terhadap siswa kelas V SDN. Pantaran yang berjumlah 14 anak. Sementara uji coba skala besar dilakukan terhadap siswa SDN. 2 Kalipetir Pengasih yang berjumlah 40 anak

\section{Jenis Data}

Data yang dikumpulan dari penelitian ini berupa data kualitatif dan kuantitatif. Data kualitiatif diperoleh dari: (a) hasil wawancara dengan guru SD; (b) data saran dan masukan perbaikan model permainan dari ahli materi serta guru pelaku uji coba. Data kuantitatif diperoleh diperoleh dari ahli materi terhadap: (a) penilainan ahli materi terhadap permainan; (b) penilaian ahli materi terhadap karakter yang muncul pada setiap permainan; (c) penilaian ahli materi terhadap guru pelaku uji coba.

\section{Instrumen Pengumpulan Data}

\section{Wawancara}

Wawancara digunakan sebagai teknik pengumpulan data apabila peneliti ingin melakukan studi pendahuluan untuk menemukan permasalahan yang harus diteliti, dan juga apabila peneliti ingin mengetahui hal-hal dari responden yang lebih mendalam dan jumlah respondennya sedikit/kecil (Sugiyono, 2007, p.138).

Teknik pengumpulan data yang digunakan yaitu teknik komunikasi langsung dengan menggunakan instrumen wawancara sebagai alat pengumpul data. Definisi dari teknik komunikasi langsung adalah mekanisme pengumpulan data yang dilakukan melalui kontak atau hubungan pribadi dalam bentuk tatap muka (face to face relationship) antara pengumpul data dengan responden, sedangkan wawancara adalah alat pengumpul data berupa tanya jawab antara pihak pencari informasi (interviewer) dengan sumber informasi (responden/interviewee) yang berlangsung secara lisan (Nawawi 2006, p.98). Untuk merekam hasil wawancara digunakan handphone. 


\section{Skala Nilai (Rating Scale)}

Instrumen pengumpul data kedua yang digunakan yaitu skala nilai. Skala nilai ini digunakan untuk menilai kelayakan model permainan yang dikembangkan sebelum pelaksanaan uji coba skala kecil. Setelah para ahli menilai bahwa model permainan sudah sesuai dengan unsur-unsur dalam skala nilai, model permainan baru dapat diujicobakan dalam uji coba skala kecil. Dalam skala nilai, variabel atau tujuan penelitian diklasifikasikan secara rinci menjadi gejala-gejala dengan unsur-unsurnya. Klasifikasi tersebut disusun ke bawah, sedangkan ke samping dicantumkan kategori sesuai dengan maksud/tujuan penelitian, antara lain berupa urutan kualitas data yang dikumpulkan. Kategori yang dimaksud dalam skala penilaian ini adalah kategori berskala dua, yaitu sesuai dan tidak sesuai. Cara penggunaan skala nilai yaitu, bilamana muncul gejala atau unsur-unsur seperti yang terdapat dalam klasifikasi data, para pakar dan guru memberikan tanda cek $(\sqrt{ })$ pada kolom kategori yang sesuai. Apabila gejala atau unsur-unsur seperti yang terdapat dalam klasifikasi data dinyatakan sesuai maka nilainya satu (1), apabila dinyatakan tidak sesuai maka nilainya nol (0).

\section{Instrumen Observasi}

Teknik pengumpulan data ketiga yang digunakan yaitu teknik observasi tidak langsung dengan instrumen observasi berupa daftar cek (check list) dan peralatan mekanik. Observasi sebagai teknik pengumpulan data mempunyai ciri yang spesifik bila dibandingkan dengan teknik yang lain, yaitu wawancara dan kuesioner. Teknik pengumpulan data dengan observasi digunakan bila penelitian berkenaan dengan perilaku manusia, proses kerja, gejala-gejala alam dan bila responden yang di amati terlalu besar (Sugiyono, 2007, p.145). Teknik observasi tidak langsung merupakan cara mengumpulkan data yang dilakukan melalui pengamatan dan pencatatan gejala-gejala yang tampak pada objek penelitian yang dilaksanakan setelah peristiwa atau situasi atau keadaannya terjadi.

Dalam daftar cek, variabel penelitian dijabarkan secara rinci berupa gejala-gejala atau unsur-unsur di dalam setiap gejala, sebagai klasifikasi data yang perlu dihimpun. Rincian gejala dan unsur-unsurnya disusun secara teratur menjadi suatu daftar sebagai urutan klasifikasi data yang akan diamati muncul atau tidaknya di dalam suatu peristiwa, keadaan/situasi/kejadian yang berkenaan dengan masalah penelitian (Nawawi, pp.76-77).

\section{Instrumen Penilaian Anak}

Instrumen penilaian anak adalah format penilaian yang digunakan guru untuk menilai kinerja anak saat melaksanakan permainan-permainan yang dikembangkan. Dengan format penilaian ini akan memudahkan guru dalam mengevaluasi penampilan anak dan ketercapaian indikator yang diharapkan dari tiap permainan. Terdapat enam format penilaian untuk enam permainan yang dikembangkan. Format penilaian untuk masing-masing permainan berbeda karena indikator tujuan permainan yang berbedabeda dalam tiap permainan. Kisi-kisi format penilaian anak sama dengan kisi-kisi instrumen untuk mengobservasi keefektifan model permainan.

\section{Hasil Penelitian dan Pembahasan}

Hasil penilaian para ahli dan guru di lapangan terhadap model pembelajaran permainan dalam membentuk karakter kerja sama, tanggung jawab dan kejujuran meliputi. (1) observasi terhadap model permainan, (2) data penilaian terhadap karakter yang muncul dalam permainan.

\section{Permainan Perang Bola}

Tabel 1.Data Skala Besar Ahli dan Guru Terhadap Permainan "Perang Bola"

\begin{tabular}{ccccccccc}
\hline \multirow{2}{*}{ Ahli Materi } & \multicolumn{7}{c}{ Aspek Penilaian } & \multirow{2}{*}{ Skor } \\
\cline { 2 - 8 } & $\mathbf{1}$ & $\mathbf{2}$ & $\mathbf{3}$ & $\mathbf{4}$ & $\mathbf{5}$ & $\mathbf{6}$ & $\mathbf{7}$ & \\
\hline Pakar 1 & 1 & 1 & 1 & 1 & 1 & 1 & 1 & 7 \\
Pakar 2 & 1 & 1 & 1 & 1 & 1 & 1 & 1 & 7 \\
Guru 1 & 1 & 1 & 1 & 1 & 1 & 1 & 1 & 7 \\
Guru 2 & 1 & 1 & 1 & 1 & 1 & 1 & 1 & 7 \\
\hline
\end{tabular}

Nilai Maksimal $=28$

A: Nilai yang diperoleh, B: Nilai maksimal $\mathrm{A} / \mathrm{B} \times 100 \%$

$28 / 28 \times 100=100 \%=$ Kategori sangat baik

Berdasarkan penilaian uji coba skala besar dari guru dan ahli terhadap model permainan perang bola terlihat bahwa hasil yang didapat menunjukkan nilai maksimal yaitu 28 dengan persentase $100 \%$. Dengan hasil tersebut dapat disimpulkan bahwa model permainan ini sangat baik untuk digunakan dalam pembelajaran. 
Tabel 2.Data Skala Besar Ahli Terhadap Karakter yang Muncul pada Permainan "Perang Bola"

\begin{tabular}{|c|c|c|c|c|c|c|c|c|}
\hline \multirow{2}{*}{ Ahli Materi } & \multicolumn{7}{|c|}{ Aspek Penilaian } & \multirow{2}{*}{ Skor } \\
\hline & 1 & 2 & 3 & 4 & 5 & 6 & 7 & \\
\hline Pakar 1 & 1 & 1 & 1 & 1 & 1 & 1 & 1 & 7 \\
\hline Pakar 2 & 1 & 1 & 1 & 1 & 1 & 1 & 1 & 7 \\
\hline Guru 1 & 1 & 1 & 1 & 1 & 1 & 1 & 1 & 7 \\
\hline Guru 2 & 1 & 1 & 1 & 1 & 1 & 1 & 1 & 7 \\
\hline
\end{tabular}

Keterangan:

Nilai Maksimal $=28$

A: Nilai yang diperoleh, B: Nilai maksimal $\mathrm{A} / \mathrm{B} \times 100 \%$

$28 / 28 \times 100=100 \%=$ Kategori sangat baik

Berdasarkan penilaian uji coba skala besar dari para ahli terhadap karakter yang muncul pada model permainan perang bola. Terlihat bahwa hasil yang didapat telah menunjukkan nilai maksimal yaitu $100 \%$ yang berada dalam kategori sangat baik. Dari hasil tersebut dapat disimpulkan model permainan ini sangat baik untuk mentransfer nilai-nilai kejujuran pada diri siswa.

\section{Permainan Berburu Kancil}

Tabel 3. Data Ahli dan Guru Terhadap Permainan "Berburu Kancil"

\begin{tabular}{|c|c|c|c|c|c|c|c|c|}
\hline \multirow{2}{*}{ Ahli Materi } & \multicolumn{7}{|c|}{ Aspek Penilaian } & \multirow{2}{*}{ Skor } \\
\hline & $\mathbf{1}$ & 2 & 3 & 4 & 5 & 6 & 7 & \\
\hline Pakar 1 & 1 & 1 & 1 & 1 & 1 & 1 & 1 & 7 \\
\hline Pakar 2 & 1 & 1 & 1 & 1 & 1 & 1 & 1 & 7 \\
\hline Guru 1 & 1 & 1 & 1 & 1 & 1 & 1 & 1 & 7 \\
\hline Guru 2 & 1 & 1 & 1 & 1 & 1 & 1 & 1 & 7 \\
\hline
\end{tabular}

Keterangan:

Nilai Maksimal $=28$

A: Nilai yang diperoleh, B: Nilai maksimal A/B X $100 \%$

$28 / 28 \times 100=100 \%=$ Kategori sangat baik

Berdasarkan penilaian uji coba skala besar dari para ahli terhadap model permainan berburu kancil terlihat bahwa hasil yang didapat menunjukkan nilai maksimal yaitu 28 dengan persentase $100 \%$. Dengan hasil tersebut dapat disimpulkan bahwa model permainan ini sangat bak untuk digunakan dalam pembelajaran.

Tabel 4. Data Ahli dan Guru Terhadap

Karakter yang Muncul pada

Permainan"Berburu Kancil"

\begin{tabular}{ccccccccc}
\hline \multirow{2}{*}{ Ahli Materi } & \multicolumn{7}{c}{ Aspek Penilaian } & \multirow{2}{*}{ Skor } \\
\cline { 2 - 7 } & $\mathbf{1}$ & $\mathbf{2}$ & $\mathbf{3}$ & $\mathbf{4}$ & $\mathbf{5}$ & $\mathbf{6}$ & $\mathbf{7}$ & \\
\hline Pakar 1 & 1 & 1 & 1 & 1 & 1 & 1 & 1 & 7 \\
Pakar 2 & 1 & 1 & 1 & 1 & 1 & 1 & 1 & 7 \\
Guru 1 & 1 & 1 & 1 & 1 & 1 & 1 & 1 & 7 \\
Guru 2 & 1 & 1 & 1 & 1 & 1 & 1 & 1 & 7 \\
\hline
\end{tabular}

Keterangan:

Nilai Maksimal $=24$
A: Nilai yang diperoleh, B: Nilai maksimal

A $/$ B X $100 \%$

$24 / 24 \times 100=100 \%=$ Kategori sangat baik

Berdasarkan penilaian uji coba skala besar dari para ahli terhadap karakter yang muncul pada permainan berburu kancil. Terlihat bahwa hasil yang didapat telah menunjukkan nilai maksimal yaitu $100 \%$ yang berada dalam kategori sangat baik. Dari hasil tersebut dapat disimpulkan model permainan ini sangat baik untuk mentransfer nilai-nilai kejujuran pada diri siswa.

Permainan Memasukkan Bola ke Simpai

Tabel 5. Data Ahli dan Guru Terhadap

Model Permainan "Memasukkan Bola ke Simpai"

\begin{tabular}{ccccccccc}
\hline \multirow{2}{*}{ Ahli Materi } & \multicolumn{10}{c}{ Aspek Penilaian } & \multirow{2}{*}{ Skor } \\
\cline { 2 - 7 } & $\mathbf{1}$ & $\mathbf{2}$ & $\mathbf{3}$ & $\mathbf{4}$ & $\mathbf{5}$ & $\mathbf{6}$ & $\mathbf{7}$ & \\
\hline Pakar 1 & 1 & 1 & 1 & 1 & 1 & 1 & 1 & 7 \\
Pakar 2 & 1 & 1 & 1 & 1 & 1 & 1 & 1 & 7 \\
Guru 1 & 1 & 1 & 1 & 1 & 1 & 1 & 1 & 7 \\
Guru 2 & 1 & 1 & 1 & 1 & 1 & 1 & 1 & 7 \\
\hline
\end{tabular}

Keterangan:

Nilai Maksimal $=28$

A: Nilai yang diperoleh, B: Nilai maksimal A/B X $100 \%$

$28 / 28 \times 100=100 \%=$ Kategori sangat baik

Berdasarkan penilaian uji coba skala besar dari para ahli terhadap karakter yang muncul pada model permainan memasukkan bola ke simpai. Terlihat bahwa hasil yang didapat telah menunjukkan nilai maksimal yaitu $100 \%$ yang berada dalam kategori sangat baik. Dari hasil tersebut dapat disimpulkan model permainan ini sangat baik untuk menransfer nilai-nilai kejujuran pada diri siswa.

Tabel 6. Data Ahli dan Guru Terhadap

Karakter yang Muncul pada

Permainan"Memasukkan Bola ke Simpai"

\begin{tabular}{|c|c|c|c|c|c|c|c|c|}
\hline \multirow{2}{*}{ Ahli Materi } & \multicolumn{7}{|c|}{ Aspek Penilaian } & \multirow[b]{2}{*}{ Skor } \\
\hline & 1 & 2 & 3 & 4 & 5 & 6 & 7 & \\
\hline Pakar 1 & 1 & 1 & 1 & 1 & 1 & 1 & 1 & 7 \\
\hline Pakar 2 & 1 & 1 & 1 & 1 & 1 & 1 & 1 & 7 \\
\hline Guru 1 & 1 & 1 & 1 & 1 & 1 & 1 & 1 & 7 \\
\hline Guru 2 & 1 & 1 & 1 & 1 & 1 & 1 & 1 & 7 \\
\hline
\end{tabular}

Keterangan:

Nilai Maksimal $=24$

A: Nilai yang diperoleh, B: Nilai maksimal

A/B X $100 \%$

$24 / 24 \times 100=100 \%=$ Kategori sangat baik

Berdasarkan penilaian uji coba skala besar dari para ahli terhadap karakter yang muncul pada permainan berburu kancil. Terlihat bahwa hasil yang didapat telah menunjukkan 
nilai maksimal yaitu $100 \%$ yang berada dalam kategori sangat baik. Dari hasil tersebut dapat disimpulkan model permainan ini sangat baik untuk mentransfer nilai-nilai tanggungjawab pada diri siswa.

Permainan Golku Keranjangku

Tabel 7. Data Ahli dan Guru Ahli Terhadap Permainan "Golku Keranjangku"

\begin{tabular}{|c|c|c|c|c|c|c|c|c|}
\hline \multirow{2}{*}{ Ahli Materi } & \multicolumn{7}{|c|}{ Aspek Penilaian } & \multirow{2}{*}{ Skor } \\
\hline & 1 & 2 & 3 & 4 & 5 & 6 & 7 & \\
\hline Pakar 1 & 1 & 1 & 1 & 1 & 1 & 1 & 1 & 7 \\
\hline Pakar 2 & 1 & 1 & 1 & 1 & 1 & 1 & 1 & 7 \\
\hline Guru 1 & 1 & 1 & 1 & 1 & 1 & 1 & 1 & 7 \\
\hline Guru 2 & 1 & 1 & 1 & 1 & 1 & 1 & 1 & 7 \\
\hline
\end{tabular}

Keterangan:

Nilai Maksimal $=28$

A: Nilai yang diperoleh, B: Nilai maksimal $\mathrm{A} / \mathrm{B} \times 100 \%$

$28 / 28 \times 100=100 \%=$ Kategori sangat baik

Berdasarkan penilaian uji coba skala besar dari para ahli terhadap model permainan gol ku keranjangku terlihat bahwa hasil yang didapat menunjukkan nilai maksimal yaitu 28 dengan persentase $100 \%$. Dengan hasil tersebut dapat disimpulkan bahwa model permainan ini sangat baik untuk digunakan dalam pembelajaran.

Tabel 8. Data Ahli dan Guru Terhadap Karakter yang Muncul pada Permainan"Golku Keranjangku"

\begin{tabular}{|c|c|c|c|c|c|c|c|c|}
\hline \multirow{2}{*}{ Ahli Materi } & \multicolumn{7}{|c|}{ Aspek Penilaian } & \multirow{2}{*}{ Skor } \\
\hline & 1 & 2 & 3 & 4 & 5 & 6 & 7 & \\
\hline Pakar 1 & 1 & 1 & 1 & 1 & 1 & 1 & 1 & 7 \\
\hline Pakar 2 & 1 & 1 & 1 & 1 & 1 & 1 & 1 & 7 \\
\hline Guru 1 & 1 & 1 & 1 & 1 & 1 & 1 & 1 & 7 \\
\hline Guru 2 & 1 & 1 & 1 & 1 & 1 & 1 & 1 & 7 \\
\hline
\end{tabular}

Keterangan:

Nilai Maksimal $=28$

A: Nilai yang diperoleh, B: Nilai maksimal

$\mathrm{A} / \mathrm{B} \times 100 \%$

$28 / 28 \times 100=100 \%=$ Kategori sangat baik

Berdasarkan penilaian uji coba skala besar dari para ahli terhadap karakter yang muncul pada permainan berburu kancil. Terlihat bahwa hasil yang didapat telah menunjukkan nilai maksimal yaitu $100 \%$ yang berada dalam kategori sangat baik. Dari hasil tersebut dapat disimpulkan model permainan ini sangat baik untuk mentransfer nilai-nilai tanggungjawab pada diri siswa.
Permainan Lempar Tangkap

Tabel 9. Data dari Ahli dan Guru Terhadap Permainan "Lempar Tangkap"

\begin{tabular}{|c|c|c|c|c|c|c|c|c|}
\hline \multirow{2}{*}{ Ahli Materi } & \multicolumn{7}{|c|}{ Aspek Penilaian } & \multirow{2}{*}{ Skor } \\
\hline & $\mathbf{1}$ & 2 & 3 & 4 & 5 & 6 & 7 & \\
\hline Pakar 1 & 1 & 1 & 1 & 1 & 1 & 1 & 1 & 7 \\
\hline Pakar 2 & 1 & 1 & 1 & 1 & 1 & 1 & 1 & 7 \\
\hline Guru 1 & 1 & 1 & 1 & 1 & 1 & 1 & 1 & 7 \\
\hline Guru 2 & 1 & 1 & 1 & 1 & 1 & 1 & 1 & 7 \\
\hline
\end{tabular}

Keterangan:

Nilai Maksimal $=28$

A: Nilai yang diperoleh, B: Nilai maksimal

A/B X $100 \%$

$28 / 28 \times 100=100 \%=$ Kategori sangat baik

Berdasarkan penilaian uji coba skala besar dari para ahli terhadap model permainan berburu kancil terlihat bahwa hasil yang didapat menunjukkan nilai maksimal yaitu 28 dengan persentase $100 \%$. Dengan hasil tersebut dapat disimpulkan bahwa model permainan ini sangat bak untuk digunakan dalam pembelajaran.

Tabel 10. Data Ahli dan Guru Terhadap Karakter yang Muncul pada Permainan"Lempar Tangkap "

\begin{tabular}{ccccccccc}
\hline \multirow{2}{*}{ Ahli Materi } & \multicolumn{10}{c}{ Aspek Penilaian } & \multirow{2}{*}{ Skor } \\
\cline { 2 - 7 } & $\mathbf{1}$ & $\mathbf{2}$ & $\mathbf{3}$ & $\mathbf{4}$ & $\mathbf{5}$ & $\mathbf{6}$ & $\mathbf{7}$ & \\
\hline Pakar 1 & 1 & 1 & 1 & 1 & 1 & 1 & 1 & 7 \\
Pakar 2 & 1 & 1 & 1 & 1 & 1 & 1 & 1 & 7 \\
Guru 1 & 1 & 1 & 1 & 1 & 1 & 1 & 1 & 7 \\
Guru 2 & 1 & 1 & 1 & 1 & 1 & 1 & 1 & 7 \\
\hline
\end{tabular}

Keterangan:

Nilai Maksimal $=28$

A: Nilai yang diperoleh, B: Nilai maksimal

A/B X $100 \%$

$28 / 28 \times 100=100 \%=$ Kategori sangat baik

Berdasarkan penilaian uji coba skala besar dari para ahli terhadap karakter yang muncul pada permainan lempar tangkap terlihat bahwa hasil yang didapat telah menunjukkan nilai maksimal yaitu $100 \%$ yang berada dalam kategori sangat baik. Dari hasil tersebut dapat disimpulkan bahwa model permainan ini sangat baik untuk menanamkan nilai-nilai kerja sama pada diri.

Permainan Sentuh Bola

Tabel 11. Data Ahli dan Guru Ahli Terhadap Permainan "Golku Keranjangku"

\begin{tabular}{|c|c|c|c|c|c|c|c|c|}
\hline \multirow{2}{*}{ Ahli Materi } & \multicolumn{7}{|c|}{ Aspek Penilaian } & \multirow{2}{*}{ Skor } \\
\hline & $\mathbf{1}$ & 2 & 3 & 4 & 5 & 6 & 7 & \\
\hline Pakar 1 & 1 & 1 & 1 & 1 & 1 & 1 & 1 & 7 \\
\hline Pakar 2 & 1 & 1 & 1 & 1 & 1 & 1 & 1 & 7 \\
\hline Guru 1 & 1 & 1 & 1 & 1 & 1 & 1 & 1 & 7 \\
\hline Guru 2 & 1 & 1 & 1 & 1 & 1 & 1 & 1 & 7 \\
\hline
\end{tabular}


Keterangan:

Nilai Maksimal $=28$

A: Nilai yang diperoleh, B: Nilai maksimal

A / B X $100 \%$

$28 / 28 \times 100=100 \%=$ Kategori sangat baik

Berdasarkan penilaian uji coba skala besar dari para ahli terhadap model permainan sentuh bola ke tubuh lawan terlihat bahwa hasil yang didapat menunjukkan nilai maksimal yaitu 28 dengan persentase $100 \%$. Dengan hasil tersebut dapat disimpulkan bahwa model permainan ini sangat baik untuk digunakan dalam pembelajaran.

Tabel 12. Data Ahli dan Guru Terhadap Karakter yang Muncul pada Permainan "Sentuh Bola"

\begin{tabular}{|c|c|c|c|c|c|c|c|c|}
\hline \multirow{2}{*}{ Ahli Materi } & \multicolumn{7}{|c|}{ Aspek Penilaian } & \multirow{2}{*}{ Skor } \\
\hline & 1 & 2 & 3 & 4 & 5 & 6 & 7 & \\
\hline Pakar 1 & 1 & 1 & 1 & 1 & 1 & 1 & 1 & 7 \\
\hline Pakar 2 & 1 & 1 & 1 & 1 & 1 & 1 & 1 & 7 \\
\hline Guru 1 & 1 & 1 & 1 & 1 & 1 & 1 & 1 & 7 \\
\hline Guru 2 & 1 & 1 & 1 & 1 & 1 & 1 & 1 & 7 \\
\hline
\end{tabular}

Keterangan:

Nilai Maksimal $=28$

A: Nilai yang diperoleh, B: Nilai maksimal

$\mathrm{A} / \mathrm{B} \times 100 \%$

$28 / 28 \times 100=100 \%=$ Kategori sangat baik

Berdasarkan penilaian uji coba skala besar dari para ahli terhadap keefektifan model permainan sentuh bola ke tubuh lawan terlihat bahwa hasil yang didapat telah menunjukkan nilai maksimal yaitu $100 \%$ yang berada dalam kategori sangat baik. Dari hasil tersebut dapat disimpulkan bahwa model permainan ini sangat baik untuk menanamkan nilai-nilai kerja sama pada diri siswa.

\section{Latihan Pendahuluan (15 Menit)}

Saat pembelajaran dimulai pertama guru menyiapkan peserta didik serta memimpin doa tanda pembelajaran akan dimulai, kemudian melakukan apersepsi dengan menjelaskan aturan permainan bom ikan dan perang bola serta tujuan dalam permainan tersebut. Kemudian guru memberikan kesempatan kepada siswa untuk bertanya apabila ada siswa yang belum mengerti.

Setelah itu guru memberikan latihan pemanasan kepada siswa dengan tujuan meningkatkan suhu tubuh peserta didik agar dapat meminimalisir cedera. Bentuk pemanasan yang diberikan yaitu berupa stretching statis dan pemanasan dinamis berupa game. Adapun game yang diberikan oleh guru adalah pertama siswa diintruksikan oleh guru untuk melakukan joging. Setelah itu guru memberi aba-aba dengan isyarat tangan dengan menunjuk angka 3 , maka siswa berusaha mencari temannya sebanyak 3 orang, guru juga dapat memberikan interuksi dengan kata-kata berupa benda yang ada di sekitar sekolah, contohnya guru menyebut "pohon" maka siswa berusaha berlari ke arah pohon tersebut demikian seterusnya guru memberikan aba-aba dan siswa yang melakukannya.

Latihan Inti

\section{Permainan Berburu Kancil (10 Menit)}

Permainan ini bertujuan untuk mengembangkan aspek biomotor dan karakter siswa. Adapun aspek biomotor yang berpengaruh yaitu: (1) kekuatan, (2) kelincahan dan (3) kemampuan koordinasi siswa dalam melempar dan menangkap bola. Selain aspek biomotor permainan ini juga memfokuskan kepada pengembangan karakter siswa khususnya dalam hal kejujuran antara lain: (1) mau mentaati peraturan permainan, (2) tidak bermain curang, dan (3) mau mengakui kesalahan apabila melanggar peraturan.

Siswa dibagi menjadi dua tim yaitu tim yang menjadi pemburu yang berada di luar lapangan dan yang menjadi kancil yang berada di dalam lapangan. Masing-masing berjumlah 8-10 siswa. Permainan dilakukan dengan cara lempar tangkap serta menembak bola hingga mengenai tim yang berperan sebagai kancil yang berada di dalam lapangan. Bola yang digunakan pada permainan ini adalah bola modifikasi yang terbuat dari bahan karet. Tim yang berada di dalam lapangan berusaha mengindari lemparan bola dari tim pemburu. Permainan dibuat dengan dua sesi yaitu dengan cara bergantian peran antara tim yang menjadi pemburu dan yang menjadi kancil. Setiap sesi permainan dibatasi waktu 10 menit. Pemenang dalam permainan ini adalah kelompok yang paling sedikit terkena lemparan dalam waktu 10 menit. Nilai yang dimunculkan dalam permainan ini adalah nilai-nilai kejujuran bagaimana siswa mentaati peraturan, berlaku jujur dan mengakui kesalahannya.

\section{Permainan Perang Bola (10 Menit)}

Permainan ini bertujuan untuk mengembangkan aspek biomotor dan karakter siswa. Adapun aspek biomotor yang berpengaruh yaitu: (1) kekuatan, (2) kelincahan dan (3) kemampuan koordinasi siswa dalam melempar 
dan menangkap bola. Selain aspek biomotor permainan ini juga memfokuskan kepada pengembangan karakter siswa khususnya dalam hal kejujuran antara lain: (1) mau mentaati peraturan permainan, (2) tidak bermain curang, dan (3) mau mengakui kesalahan apabila melanggar peraturan.

Anak dibagi menjadi dua kelompok yaitu kelompok A dan B yang masing-masing kelompok berjumlah 7-10 orang. Permainan dilakukan dalam waktu 10-15 menit. Pelaksanaan awal permainan setiap tim memposisikan dirinya di garis belakang lapangan masing-masing dan berjajar. Bola diletakan di garis tengan lapangan. Pada saat guru meniupkan peluit arti tanda permainan dimulai siswa masing-masing kelompok A dan B berlari ke garis tengah untuk berebut mendapatkan bola yang ada di garis tengah. Siswa yang mendapat bola kemudian mengoper bola ke teman kelompoknya dan berusaha melempar bola tersebut hingga mengenai kaki kelompok lawan. Pemain yang mendapat bola tidak diperbolehkan lari ataupun jalan. Jadi bola hanya boleh di oper ke teman atau dilempar ke tim lawan.

Kelompok yang menjadi sasaran lemparan berlari menghindari lemparan tersebut apabila ada siswa yang terkena lemparan. Siswa tersebut langsung memposisikan dirinya di luar garis paling belakang pada posisi lawan. Tujuannya untuk membantu kelompoknya menembak bola ke tim lawan. Apabila pada saat melempar bola tersebut tidak mengenai sasaran dan bola berada di posisi lawan maka bola tersebut akan dikuasai oleh lawan. Tim yang dinyatakan menang dalam permainan ini adalah tim yang paling banyak terkena lemparan atau yang paling banyak berada di luar lapangan. Namun inti dari permainan ini tidak hanya bagaimana setiap tim tersebut mampu melempar bola mengenai sasaran yang ditentukan. Melainkan unsur-unsur nilai-nilai kejujuran yang juga dipertimbangkan dalam permainan ini, yaitu bagaimana siswa mampu mentaati peraturan yang ada, dan mau mengakui apabila telah melanggar peraturan tersebut.

\section{Permainan Memasukkan Bola ke Simpai (10 Menit)}

Permainan ini bertujuan untuk mengembangkan aspek biomotor dan karakter siswa. Adapun aspek biomotor yang berpengaruh yaitu: (1) kekuatan, (2) kemampuan koordinasi siswa dalam melempar dan menangkap bola, (3) kecepatan dalam mengejar dan menangkap bola. Selain aspek biomotor permainan ini juga memfokuskan kepada pengembangan karakter siswa khususnya dalam hal tanggung jawab antara lain: (1) bermain dengan sungguh-sungguh, (2) berusaha memasukkan bola ke dalam simpai lawan, dan (3) menjaga simpai sendiri agar lawan tidak dapat memasukkan bola.

Siswa dibagi menjadi dua kelompok A dan $\mathrm{B}$, yang masing-masing kelompok berjumlah 6-7 siswa dan setiap kelompok memiliki 1 buah simpai yang dipasang di daerahnya masing-masing, setiap kelompok harus berusaha bekerja sama dan bertanggung jawab memasukkan bola ke dalam simpai yang berada di daerah lawan dan setiap kelompok juga berusaha bertanggung jawab dalam menjaga daerahnya agar lawan tidak dapat memasukkan bola ke dalam simpai yang berada di daerahnya. Permainan dilakukan dalam waktu 10-15 menit. Permainan dilakukan dengan cara lempar tangkap. Bola yang digunakan merupakan bola modifikasi yang terbuat dari karet. Setiap tim boleh memegang bola maksimal 2 langkah. Tim yang dinyatakan menang adalah tim yang paling banyak memasukkan bola ke dalam simpai lawan. Pada saat menembak bola ke dalam simpai tidak diperkenankan menyentuh garis atau batas lemparan. Permainan ini menekankan pada nilai karakter yang akan dikembangkan yaitu nilai tanggung jawab. Di dalam permainan ini akan melatih tanggung jawab siswa terhadap timnya maupun dirinya sendiri dalam mempertahankan daerahnya maupun melakukan serangan ke daerah lawan.

\section{Permainan Golku Keranjangku (10 Menit)}

Permainan ini bertujuan untuk mengembangkan aspek biomotor dan karakter siswa. Adapun aspek biomotor yang berpengaruh yaitu: (1) kekuatan, (2) kemampuan koordinasi siswa dalam melempar dan menangkap bola, (3) kecepatan dalam mengejar dan menangkap bola. Selain aspek biomotor permainan ini juga memfokuskan kepada pengembangan karakter siswa khususnya dalam hal tanggung jawab antara lain: (1) bermain dengan sungguh-sungguh, (2) berusaha memasukkan bola ke dalam simpai lawan, dan (3) menjaga simpai sendiri agar lawan tidak dapat memasukkan bola.

Siswa dibagi dalam dua tim masingmasing berjumlah 6-7 siswa dan setiap tim mempunyai keranjang yang harus dijaga agar lawan tidak dapat memasukkan bola ke keranjang tersebut. Permainan dilakukan dengan cara lempar tangkap dan setiap tim berusaha melem- 
par bola dan memasukkannya ke dalam keranjang lawan. Bola yang digunakan adalah bola modifikasi yang terbuat dari karet. Permainan dilakukan dalam waktu 10 menit. Tim yang dinyatakan sebagai pemenang adalah tim yang paling banyak memasukkan bola ke dalam keranjang lawan. Permainan ini memiliki nilai karakter yang akan dikembangkan yaitu nilai tanggung jawab. Di dalam permainan ini akan terlihat dan melatih tanggung jawab siswa terhadap timnya maupun dirinya sendiri dalam berusaha mempertahankan daerahnya agar tidak terjadi gol maupun melakukan serangan ke daerah lawan.

\section{Permainan Lempar Tangkap (10 Menit)}

Permainan ini bertujuan untuk mengembangkan aspek biomotor dan karakter siswa. Adapun aspek biomotor yang berpengaruh yaitu: (1) kekuatan, dan (2) kemampuan koordinasi siswa dalam melempar dan menangkap bola. Selain aspek biomotor permainan ini juga memfokuskan kepada pengembangan karakter siswa khususnya dalam hal kerja sama antara lain: (1) siswa mau bekerja sama dalam mengoper bola, (2) siswa tidak memilih teman tertentu dalam mengoper bola, (3) siswa tidak bertengkar dalam melakukan permainan.

Siswa dibagi dalam dua tim yang dipisahkan oleh tali sebagai net atau pembatas. Permainan dilakukan semacam permainan bolavoli tetapi dengan cara lempar tangkap. Peserta permainan terdiri dari 7-8 siswa dalam setiap tim. Permainan dilakukan dalam watu 10 menit. Permainan pertama dilakukan dengan servis yaitu dengan melempar bola ke daerah lawan kemudian bola ditangkap oleh lawan dan di oper sebanyak 4 kali ke rekan tim, tujuannya adalah agar terlihat aspek kerja sama dalam bermain diantara peserta didik tersebut. kemudian bola masih boleh ditangkap apabila jatuh dengan satu kali pantulan, bola dioper tidak kepada orang yang sama, setelah bola dioper sebanyak 4 kali kemudian bola dilempar ke daerah lawan. pada saat bola sampai ke daerah lawan hal yang sama dilakukan oleh tim yang memegang bola yaitu dengan mengoper bola sebanyak 4 kali. Setiap tim berusaha melempar bola ke daerah lawan dan membuat tim lawan sulit menangkapnya. Poin didapat apabila: Bola tidak di-passing 4 kali dalam setiap tim. Pada saat passing bola, ada pemain yang melakukan double passing atau 2 kali passing orang yang sama. Apabila lawan tidak mampu menangkap bola dan lebih dari satu pantulan. Apabila bola jatuh di lapang- an yang kosong dan apabila bola tidak melewati net atau tali atau bola keluar dari lapangan permainan. Tim yang dinyatakan sebagai pemenang adalah tim yang paling banyak memiliki poin.

\section{Permainan Sentuh Bola ke Tubuh Lawan (10 Menit)}

Permainan ini bertujuan untuk mengembangkan aspek biomotor dan karakter siswa. Adapun aspek biomotor yang berpengaruh yaitu: (1) kekuatan, dan (2) kelincahan, (3) daya tahan, (4) kemampuan koordinasi siswa dalam melempar dan menangkap bola. Selain aspek biomotor permainan ini juga memfokuskan kepada pengembangan karakter siswa khususnya dalam hal kerja sama antara lain: (1) siswa mau bekerja sama dalam mengoper bola, (2) siswa tidak memilih teman tertentu dalam mengoper bola, (3) siswa tidak bertengkar dalam melakukan permainan.

Siswa dibagi dalam dua kelompok yaitu kelompok yang memegang bola dan kelompok yang akan disentuh oleh bola tersebut. Dengan masing-masing kelompok berjumlah 6-7 orang siswa. Bola yang digunakan sebanyak 1 buah bola modifikasi yang terbuat dari bahan karet. Permainan dilakukan dalam waktu 10 menit. Permainan dilakukan dengan cara lempar tangkap kemudian menyentuhkan bola tersebut ke tubuh lawan. Siswa yang memegang bola bekerja sama untuk menyentuhkan bola ke tubuh lawan dengan cara lempar tangkap. Setiap pemain yang memegang bola boleh melangkah maksimal 2 langkah, kemudian bola tersebut harus dioper dengan cara dilempar ke rekan tim yang berada dekat dengan pemain lawan untuk disentuhkan ke lawan tersebut. Pemain yang tersentuh bola langsung memposisikan diri di luar lapangan, pemain juga tidak boleh berlari keluar dari lapangan. Jika melewati lapangan maka pemain di anggap gugur. Permainan dibuat dalam dua sesi yaitu dengan cara bergantian. Tim yang dinyatakan sebagai pemenang adalah tim yang paling sedikit tersentuh oleh bola.

\section{Latihan Pendinginan}

Setelah permainan selesai siswa dipersilahkan duduk berbaris. kemudian guru menyuruh siswa untuk saling memijat punggung teman yang ada di depannya. sambil guru bertanya kepada siswa mengenai permainan yang baru saja dilakukan. 


\section{Simpulan dan Saran}

Simpulan

Dari hasil penilaian para ahli dan guru sebagai praktisi di lapangan menyatakan bahwa model pembelajaran permainan yang disusun sangat baik dan layak digunakan dalam pembelajaran untuk mengembangkan nilai-nilai karakter, kerja sama, tanggung jawab dan kejujuran. Adapun aktivitas permainan yang dikembangkan antara lain: (1) permainan berburu kancil, (2) Permainan perang bola, (3) permainan memasukkan bola ke simpai, (4) permainan golku keranjangku, (5) permainan lempar tangkap, (6) permainan sentuh bola ke tubuh lawan. Produk dari penelitian pengembangan ini yaitu buku panduan model pembelajaran penjas melalui aktivitas permainan untuk pembentukan karakter yang berjudul "Membentuk karakter dengan permainan" dengan dikembangkannya model permainan tersebut diharapkan dapat menjadi alternatif bagi guru dalam memberikan pembelajaran ke siswa untuk menanamkan nilai-nilai karakter positif khususnya, kerja sama, tanggung jawab dan kejujuran.

Saran

Saran pemanfaatan berdasarkan penelitian pengembangan ini yaitu agar model permainan yang dikembangkan dapat digunakan guru sebagai salah satu bentuk pembelajaran yang berbasis karakter dengan lebih menekankan terhadap nilai-nilai karakter yang ada dalam permainan tersebut. Untuk dapat mewujudkan hal tersebut, perlu ditingkatkan kemauan dan kesediaan guru untuk senantiasa meningkatkan kualitas pembelajaran dengan berbagai bentuk/model pembelajaran yang dapat meningkatkan minat dan kualitas siswa dalam belajar, meskipun hal tersebut berarti menambah kesibukan guru dalam menyiapkan bahan-bahan pembelajaran.

Diseminasi hasil penelitian ini dapat dilakukan melalui seminar-seminar, dan dalam bentuk pembuatan artikel. Selain itu, dapat juga dilakukan melalui penelitian tindakan kelas ataupun eksperimen dengan melibatkan guru SD untuk mengetahui efek nyata dari produk permainan ini dan dapat mengidentifikasi karakter setiap siswanya.

Untuk pengembangan produk lebih lanjut, selain berupa buku panduan permainan, produk penelitian dapat dibuat dalam bentuk CD pembelajaran. Di samping itu, perlu dilakukan penelitian yang melibatkan subjek coba lebih besar dan cakupan tempat uji coba yang lebih luas.

\section{Daftar Pustaka}

Borg, Walter R. \& Gall, Joyce P.. (1983). Educational research (an Introduciton), 4th ed. New York: Longman.

Doty, Josep. (2006). Sports build character. Journal of college and character volume VII, NO. 3, April 2006.

Milson, Andrew J. (2002). Developing a comprehensive approach to character education in the social studies. Journal proquest the social studies, 101,93,3.

Munir, Abdul. (2010). Pendidikan karakter: Membangun karakter anak sejak dari rumah. Yogyakarta: PT Pustaka Insan Madani.

Nawawi, Hadari \& Hadari, Martini. (2006). Instrumen penelitian bidang sosial. Yogyakarta: Gadjah Mada University Press.

Samani, Muchlas. (2011). Konsep dan model pendidikan karakter. Bandung: PT Remaja Rosdakarya.

Sugiyono. (2007). Metode penelitian kuantitatif, kualitatif dan $R \& D$. Bandung: Alfabeta Bandung. 